\title{
Role of the sympathetic nervous system in supporting cardiac function in essential arterial hypertension
}

\author{
Maurizio Guazzi, Fabio Magrini, Cesare Fiorentini, and Alvise Polese \\ From the Istituto di Clinica Medica II and Istituto di Ricerche Cardiovascolari, \\ University of Milan, Milan, Italy
}

Treatment of hypertension with sympathetic blocking agents may convert latent cardiac failure into overt failure. Detection of early cardiac insufficiency is desirable.

Thirty patients with essential hypertension without history or symptoms of circulatory decompensation were investigated. According to the changes induced by digitalis on the left ventricular mean rates of systolic ejection and isovolumic pressure development, they were divided into 2 groups: group I (non-responders), and group II (responders to digitalis). Seventeen (II randomly selected from group I, and 6 from group II) had treatment with reserpine and guanethidine. Despite the hypotensive response, all from group II developed, in about two weeks, obvious clinical and haemodynamic signs of left ventricular impairment, while the II from group I maintained unchanged cardiac performance. Some of the patients were treated with a diuretic as well as the antihypertensives.

The response of mean systolic ejection rates and isovolumic pressure development to digitalis seems a reliable test in estimating the degree of cardiac reserve and in predicting whether the antiadrenergic therapy is liable to induce decompensation.

No signs of failure appeared in the patients (II from group I and 2 from group II) who were treated with the diuretic combined with antiadrenergic drugs. This combination restored to pretreatment levels the parameters of myocardial function which were disturbed by the administration of the antiadrenergic drugs alone.

The different effects of chronic and acute administration of antiadrenergic agents on the function of the failing hypertensive heart, and the favourable action of the diuretic, are discussed.

Sustained systemic hypertension induces haemodynamic stress on the left ventricle. When the load on the heart is excessive, several compensatory mechanisms prevent circulatory decompensation: increase in the contractile state by the sympathetic nervous system is one of the principal mechanisms which maintain the circulation under chronic excessive loading.

Gaffney and Braunwald (1963) reported intensification of congestive failure in patients with valvular or primary myocardial disease after guanethidine therapy, and emphasized the need for caution in the use of effective antiadrenergic drugs in the treatment of patients with limited cardiac reserve. Dependent oedema, weight gain, and aggravation of heart failure were reported also in hypertensive subjects during treatment with guanethidine (Leishman, Matthews, and Smith, 1959; Dollery, EmslieSmith, and Milne, 1960; Smith, 1965a) or reserpine (Perera, 1955; Marley and Pare, 1956; Smirk and McQueen, I955; Smith, I965b). In these patients Received 26 June 1972. the degree of preceding cardiac impairment appeared to be related to the development of the untoward effects. In our experience we have been surprised by the occurrence of heart failure during guanethidine and reserpine administration in hypertensive patients with no history or clinical symptoms of circulatory decompensation. This might suggest that they had cardiac insufficiency in a latent stage, not detectable clinically, which was converted to overt failure by antiadrenergic treatment.

A method of assessing quantitatively the cardiac reserve in hypertension seems to be of theoretical and practical interest.

Digitalis increases the contractility of the failing as well of the nonfailing or normal heart (Kassebaum and Griswold, 1970); there seems, however, to be a correlation between the magnitude of the induced changes in haemodynamic parameters related to the rate of ventricular contraction, such as mean rate of systolic ejection, and the basic state of cardiac function (Murphy et al., 1964). The effects of digitalis evaluated by rate-dependent 
aspects of left ventricular function, were used as a tentative means of revealing reduced or borderline cardiac compensation in long-standing arterial hypertension.

\section{Methods}

The present study was carried out on 30 carefully selected men in hospital with primary arterial hypertension, who did not give a history nor had any clinical signs of heart failure. The latter were excluded by the usual clinical criteria, i.e. absence of oedema, basilar râles, radiological evidence of pulmonary congestion, increased venous pressure, or gallop rhythm. The functional capacity of each patient, based upon follow-up over 2 to 3 weeks before the study, was determined by using the criteria of the New York Heart Association (1964). All the patients had no or only mild exertional dyspnoea (functional class I or II). Cardiac size was estimated on the basis of physical examination and chest $x$-ray. A scale of $I+$ (minimal enlargement) to $5+$ (huge heart) was used. In order to deal with comparable cases in a homogeneous group, patients with valvular lesions, exertional angina, old myocardial infarction, or idiopathic myocardial disease in addition to hypertension, were excluded. Furthermore, only patients with a glomerular filtration rate above $50 \mathrm{ml} /$ min, who were in regular sinus rhythm, and had not received digitalis at any time in the past, or antihypertensive therapy for at least one month before entry were included.

The following protocol was used: after a follow-up of 2 to 3 weeks, the haemodynamic effects of the administration of ouabain were evaluated. Depending on the response, the patients were divided into two groups as follows: group I (non-responders) consisted of 22 patients in whom the changes in left ventricular mean rate of isovolumic pressure development and in mean rate of systolic ejection after digitalis were within ro per cent of the control values. Group II (responders) consisted of 8 patients in whom digitalis resulted in a clear-cut increase (above $20 \%$ ) both in mean rate of isovolumic pressure development and in mean rate of systolic ejection.

Six subjects out of the 8 in group II were randomly selected and treated according to an experimental design which included two periods. During the first period reserpine and guanethidine were administered, the daily dose of the former being $0.5 \mathrm{mg}$. The initial dose of the latter was $30 \mathrm{mg} /$ day which was increased progressively until a hypotensive effect was achieved, both in the supine and standing position, or signs of left ventricular failure had become manifest. The maximal daily doses of guanethidine ranged between 40 and 60 $\mathrm{mg}$, and the total duration of this treatment ranged between 13 and 17 days. During the second period a diuretic (chlorthalidone $100 \mathrm{mg} /$ day) was added. When necessary, the dose of the antiadrenergic agents was then reduced according to the degree of the hypotensive response. The lowest daily doses of reserpine and guanethidine after addition of diuretic were $0.25 \mathrm{mg}$ and $25 \mathrm{mg}$, respectively.
Between the first and the second period the haemodynamic study was repeated and the effects of digitalis were again tested on each subject. In 3 of these patients the same procedure was again carried out, for the third time, after the addition of the diuretic. The remaining 2 patients of group II had the triple drug treatment only. In both of them, after an average period of 14 days, a satisfactory hypotensive effect was achieved. The haemodynamic study was then repeated and the effects of digitalis re-evaluated.

Of the 22 digitalis-unresponsive patients (group I), II were randomly selected and treated with reserpine and guanethidine, while the remainder had the triple drug combination including chlorthalidone. The doses of the drugs and the periods of treatment were in the same range as in group II. In each of these subjects the circulatory study was repeated after treatment had induced hypotensive responses, at which time the effect of digitalis was again re-evaluated.

One patient in group II interrupted the antihypertensive treatment a few weeks after being discharged. His blood pressure again became raised and he was readmitted to the hospital. The haemodynamic effects of acute intravenous infusion of reserpine $(0.5 \mathrm{mg})$ combined to guanethidine $(0.3 \mathrm{mg} / \mathrm{kg})$ were tested in this latter patient.

The circulatory changes induced by digitalis were also evaluated in 5 normal volunteers and in 4 hypertensive subjects with overt heart failure. The subjects gave their free consent to these investigations in the full knowledge of the procedure to be undertaken.

The haemodynamic studies were performed with the subjects in the fasting state without premedication. For the measurement of right atrial pressure a polyethylene 'floating' catheter ( $1 \cdot 2 \mathrm{~mm}$ i.d.) was inserted into an antecubital vein, advanced to the right ventricle, and withdrawn under pressure-monitoring to the right atrium. An I8-gauge Teflon catheter needle, inserted into the brachial artery, was used to sample indocyanine green for cardiac output and to monitor arterial pressure. Pressures were determined with Statham P23 De and P24 Db strain gauge transducers. Dye dilution analyses of cardiac output were performed after injection of indocyanine green $(5 \mathrm{mg})$ into the right atrium and withdrawal from the brachial artery. Blood withdrawn during inscription of the indicator dilution curves was immediately reinfused except for that small amount which was necessary for calibrating the densitometer at the end of the procedure. The output signal of the cuvette densitometer (Gilford) was coupled to the input of a digital computer (Gilford). The area under each dye curve was measured by planimetry as well as by the digital computer, and the cardiac output was calculated by the standard Hamilton procedure.

According to the method indicated by Weissler, Harris, and Schoenfeld (1968), the left ventricular ejection time and the isovolumic contraction time were measured from simultaneous recordings of the electrocardiogram, the phonocardiogram, and the carotid arterial tracing. For the measurements of the left ventricular systolic time intervals, records were obtained at a paper speed of $100 \mathrm{~mm} / \mathrm{sec}$. A microphone was placed over the prae- 
cordium in a position optimal for recording the initial high frequency vibrations of the first and second heart sounds. Two microphones were sometimes necessary to define the initial vibrations of both sounds. For the carotid pulse recording a Sanborn APT/16/1 transducer was used. All the parameters were recorded on an 8channel ink recorder (Hewlett-Packard 7868/A).

Left ventricular ejection time, from the beginning of the upstroke to the trough of the incisura of the right carotid pulse tracing, and the interval between the first sound and the second heart sound $\left(S_{1} S_{2}\right)$, from the beginning of the first sound to the onset of the aortic component of the second sound, were measured directly from the records. The isovolumic contraction time was calculated by subtracting the left ventricular ejection time from $S_{1} S_{2}$. All intervals were calculated from the mean of measurements on ro consecutive beats, each read to the nearest $5 \mathrm{msec}$. The mean rate of left ventricular isovolumic pressure development was determined by dividing the brachial diastolic pressure by the isovolumic contraction time, each measured during the same Io consecutive beats. The mean systolic ejection rate was determined by dividing the stroke index by the left ventricular ejection time. Left ventricular minute work was obtained as the product of mean arterial pressure and cardiac index. Systemic vascular resistance in dynes $\mathrm{sec} \mathrm{cm}^{-5}$ was calculated from the formula:

$$
\frac{(\text { MAP - map }) \times 1332 \times 60}{\text { CO }}
$$

where MAP and map are, respectively, the mean arterial and the mean right atrial pressures in $\mathrm{mmHg}$.

All the haemodynamic observations were performed in triplicate in both the control state and after digitalis. The control measurements before digitalis were carried out at least 30 minutes after the patients lay comfortably in the bed of the laboratory. Ouabain was infused over approximately a ro-minute interval through the right atrial catheter until a dose of $0.01 \mathrm{mg} / \mathrm{kg}$ had been administered. During the period of infusion arterial and right atrial pressures, heart rate (by a Hewlett-Packard 350-3400 Cardio-Tach preamplifier), and electrocardiogram were continuously recorded. Final determinations of cardiac output, pressures, and left ventricular systolic time intervals were made 30 minutes after completion of the infusion, at a time when the observed effects had achieved a maximum stable level.

\section{Results}

Table I reports the average changes of the haemodynamic parameters before and after digitalis and the percentage changes of the control values after digitalis, in 5 normal subjects, 30 hypertensive patients without a history or clinical signs of cardiac decompensation, and 4 hypertensive subjects in overt heart failure. In this Table, as well as in Fig. I and 2 , it is evident that the percentage changes in

TABLE I Average haemodynamic values before and after digitalis

\begin{tabular}{|c|c|c|c|c|c|c|c|c|c|c|c|c|}
\hline & \multicolumn{3}{|l|}{ Normal } & \multicolumn{3}{|c|}{$\begin{array}{l}\text { Hypertensive } \\
\text { non-responders }\end{array}$} & \multicolumn{3}{|c|}{$\begin{array}{l}\text { Hypertensive } \\
\text { responders }\end{array}$} & \multicolumn{3}{|c|}{$\begin{array}{l}\text { Hypertensive in } \\
\text { failure }\end{array}$} \\
\hline & \multicolumn{3}{|c|}{ (mean values of 5 cases) } & \multicolumn{3}{|c|}{ (mean values of 22 cases) } & \multicolumn{3}{|c|}{ (mean values of 8 cases) } & \multicolumn{3}{|c|}{$\begin{array}{l}\text { (mean values of } \\
A\end{array} \underset{B}{4}$ cases) } \\
\hline Heart rate & $\begin{array}{r}68 \\
(7 \cdot 8)\end{array}$ & $\begin{array}{r}65 \\
(6 \cdot 4)\end{array}$ & $\begin{array}{l}-4.9 \\
(2 \cdot 9)\end{array}$ & $\begin{array}{r}71 \\
(8 \cdot 7)\end{array}$ & $\begin{array}{r}68 \\
(8 \cdot 4)\end{array}$ & $\begin{array}{l}-4 \cdot 4 \\
(2 \cdot 7)\end{array}$ & $\begin{array}{l}8 \mathbf{1} \\
\text { (13) }\end{array}$ & $\begin{array}{l}78 \\
(15)\end{array}$ & $\begin{array}{l}-3 \cdot 7 \\
(4 \cdot 8)\end{array}$ & $\begin{array}{l}107 \\
\text { (12) }\end{array}$ & $\begin{array}{l}94 \\
(16)\end{array}$ & $\begin{array}{l}-12 \\
(I \cdot 4)\end{array}$ \\
\hline $\begin{array}{l}\text { Mean arterial pressure } \\
(\mathrm{mmHg})\end{array}$ & $\begin{array}{r}91 \\
(4 \cdot 7)\end{array}$ & $\begin{array}{r}92 \\
(5 \cdot 9)\end{array}$ & $\begin{array}{l}-I \cdot I \\
(2 \cdot 3)\end{array}$ & $\begin{array}{l}142 \\
(21)\end{array}$ & $\begin{array}{l}140 \\
(18)\end{array}$ & $\begin{array}{l}-1 \cdot 3 \\
(4 \cdot 3)\end{array}$ & $\begin{array}{l}\text { I66 } \\
(27)\end{array}$ & $\begin{array}{l}162 \\
(2 I)\end{array}$ & $(6)^{-2 \cdot 3}$ & $\begin{array}{l}\text { I77 } \\
\text { (I4) }\end{array}$ & $\begin{array}{r}166 \\
(0.9)\end{array}$ & $(2 \cdot 4)^{-6 \cdot 1}$ \\
\hline $\begin{array}{l}\text { Mean right atrial pres- } \\
\text { sure (mmHg) }\end{array}$ & $\left(\begin{array}{r}3 \\
(1 \cdot 5)\end{array}\right.$ & $(0 \cdot 7)^{3}$ & (I) & $\left(r \cdot 4^{3 \cdot 2}\right.$ & $\begin{array}{l}2 \cdot 8 \\
(I \cdot 5)\end{array}$ & $\begin{array}{l}-1 \cdot 1 \\
(2 \cdot 8)\end{array}$ & $(2 \cdot 8)^{2 \cdot 8}$ & $(3 \cdot 4)^{2 \cdot 2}$ & $\begin{array}{l}-2 \cdot 2 \\
(3 \cdot 4)\end{array}$ & $(I)^{8 \cdot 2}$ & $(1 \cdot 2)^{3 \cdot 1}$ & $\begin{array}{l}-6 \mathrm{I} \cdot 7 \\
(\mathrm{I2} \cdot 8)\end{array}$ \\
\hline $\begin{array}{l}\text { Cardiac index } \\
\left(\mathrm{ml} / \mathrm{min} / \mathrm{m}^{2}\right)\end{array}$ & $\begin{array}{l}3350 \\
(596)\end{array}$ & $\begin{array}{l}3225 \\
(495)\end{array}$ & $\begin{array}{l}-3 \cdot 6 \\
(6 \cdot 8)\end{array}$ & $\begin{array}{l}2735 \\
(606)\end{array}$ & $\begin{array}{l}2660 \\
(579)\end{array}$ & $\begin{array}{l}-2 \cdot 6 \\
(4 \cdot 5)\end{array}$ & $\begin{array}{l}2218 \\
(442)\end{array}$ & $\begin{array}{l}2504 \\
(544)\end{array}$ & $\begin{array}{l}+12.8 \\
(9.5)\end{array}$ & $\begin{array}{l}3150 \\
(155)\end{array}$ & $\begin{array}{l}3850 \\
(312)\end{array}$ & $\begin{array}{l}+22 \\
(2 \cdot 5)\end{array}$ \\
\hline $\begin{array}{l}\text { Systemic vascular re- } \\
\text { sistance (dynes sec } \\
\text { cm }^{-5} \text { ) }\end{array}$ & $\begin{array}{l}1267 \\
(209)\end{array}$ & $\begin{array}{l}1370 \\
\text { (191) }\end{array}$ & $\begin{array}{l}+7 \cdot 2 \\
(8)\end{array}$ & $\begin{array}{l}2328 \\
(716)\end{array}$ & $\begin{array}{l}2355 \\
(714)\end{array}$ & $\begin{array}{l}+1 \cdot 1 \\
(4 \cdot 7)\end{array}$ & $\begin{array}{l}3504 \\
(\text { II82) }\end{array}$ & $\begin{array}{l}2986 \\
(84 I)\end{array}$ & $\begin{array}{l}-14 \cdot 5 \\
(\text { II. }\end{array}$ & $\begin{array}{l}2314 \\
(42)\end{array}$ & $\begin{array}{l}1953 \\
(315)\end{array}$ & $\begin{array}{l}-12 \cdot 7 \\
(3 \cdot 8)\end{array}$ \\
\hline $\begin{array}{l}\text { Left ventricular work } \\
(\mathrm{kp} \mathrm{m} / \mathrm{min})\end{array}$ & $(0 .)^{3}$ & $(0.5)^{2.95}$ & $\frac{-2}{(2 \cdot 5)}$ & $(\mathrm{I})^{3.85}$ & $(\mathrm{I})^{3 \cdot 75}$ & $\begin{array}{l}-2 \cdot 8 \\
(8 \cdot 2)\end{array}$ & (I) 3.65 & $(I)^{4}$ & $\begin{array}{l}+10 \\
(14 \cdot 5)\end{array}$ & $(0.7)^{5.55}$ & $(0.5)^{6.35}$ & $\begin{array}{c}+13 \\
(3 \cdot 4)\end{array}$ \\
\hline $\begin{array}{l}\text { Left ventricular iso- } \\
\text { volumic contraction } \\
\text { time (msec) }\end{array}$ & $\begin{array}{r}38 \\
(6 \cdot 3)\end{array}$ & $\begin{array}{r}36 \\
(4 \cdot 7)\end{array}$ & $\begin{array}{l}-6 \\
(3 \cdot 8)\end{array}$ & $\begin{array}{r}52 \\
(8 \cdot 7)\end{array}$ & $\begin{array}{r}49 \\
(9 \cdot 2)\end{array}$ & $\begin{array}{l}-6 \cdot 8 \\
(8 \cdot 3)\end{array}$ & $\begin{array}{c}58 \\
(10 \cdot 7)\end{array}$ & $\begin{array}{c}42 \\
(11 \cdot 7)\end{array}$ & $\begin{array}{l}-27 \cdot 3 \\
(10 \cdot 2)\end{array}$ & $(7)^{40}$ & $\begin{array}{l}20 \\
(14)\end{array}$ & $\begin{array}{l}-50 \\
(15)\end{array}$ \\
\hline $\begin{array}{l}\text { Mean systolic ejection } \\
\text { rate }\left(\mathrm{ml} / \mathrm{sec} / \mathrm{m}^{2}\right)\end{array}$ & $\begin{array}{l}146 \\
(5 I)\end{array}$ & $\begin{array}{l}152 \\
(56)\end{array}$ & $\begin{array}{l}+3 \cdot 4 \\
(6 \cdot 6)\end{array}$ & $\begin{array}{l}138 \\
(3 I)\end{array}$ & $\begin{array}{l}139 \\
(30)\end{array}$ & $\begin{array}{l}+0.7 \\
(4 \cdot 2)\end{array}$ & $\begin{array}{l}\text { Iro } \\
(45)\end{array}$ & $\begin{array}{l}138 \\
(69)\end{array}$ & $\begin{array}{l}+25 \\
(5)\end{array}$ & $\begin{array}{r}\mathbf{r} 4 \mathbf{I} \\
(I \cdot 4)\end{array}$ & $\begin{array}{l}198 \\
(18)\end{array}$ & $\begin{array}{l}+40 \\
(7 \cdot 3)\end{array}$ \\
\hline $\begin{array}{l}\text { Mean isovolumic pres- } \\
\text { sure development } \\
\text { rate }(\mathrm{mmHg} / \mathrm{msec})\end{array}$ & $\begin{array}{c}1 \cdot 8 \\
(0.12)\end{array}$ & $\begin{array}{l}1 \cdot 8 \\
(0 \cdot 16)\end{array}$ & $\begin{array}{c}0 \\
(2 \cdot 5)\end{array}$ & $(0.3)^{2.05}$ & $(0 \cdot 3)^{2 \cdot I}$ & $\begin{array}{l}+2 \cdot 4 \\
(6)\end{array}$ & $(0.5)^{2.17}$ & $(0.8)^{3.05}$ & $\begin{array}{l}5+40.5 \\
(18)\end{array}$ & $(0.9)^{3.3}$ & $\begin{array}{r}8 \\
(5 \cdot 6)\end{array}$ & $\begin{array}{l}+141 \\
(116)\end{array}$ \\
\hline
\end{tabular}

A, control; B, after digitalis; \%, percentage change in control values. SD in parentheses. 
mean rate of systolic ejection and mean rate of isovolumic pressure development induced by digitalis are in a range quite similar to that of the normal subjects of group I (non-responders), while changes of the same parameters in patients of group II (responders) tend to approach the range of the decompensated subjects.

Table 2 gives a summary of the clinical findings in 30 hypertensive patients, again separated into groups I and II. Review of the clinical information was considered to be of importance in determining whether responders and non-responders showed differences in clinical patterns. It is seen from this Table that age distribution, duration, and severity of hypertension, fundi, glomerular filtration rate, electrocardiographic pattern, and heart size showed a wide overlap between the two groups.

The influence of the antihypertensive treatment on the performance of the left ventricle was evaluated on the basis of the clinical symptoms, the haemodynamic changes as induced on the pretreatment control measurements, and the circulatory response to digitalis. Six patients in group II who were treated with reserpine and guanethidine all developed clinical signs of left ventricular failure, i.e. nocturnal dyspnoea and basilar lung râles. Their body weight was checked daily, and a moderate but definite weight gain was detected. Cardiac performance, as indicated by the values of mean right atrial pressures, cardiac index, mean rate of systolic ejection, and mean rate of isovolumic pressure development, reported in Table 3, was significantly reduced after antiadrenergic treatment despite lower pressure load. Mean arterial pressure, in fact, showed an average reduction of about $30 \mathrm{mmHg}$. After antiadrenergic therapy the effectiveness of digitalis was enhanced (Table 3, Fig. I and 2). The digitalis induced percentage changes in cardiac index, mean rate of systolic ejection, and mean rate of isovolumic pressure development as compared to the pretreatment control, which were highly significant. On the contrary, the 2 patients of this 


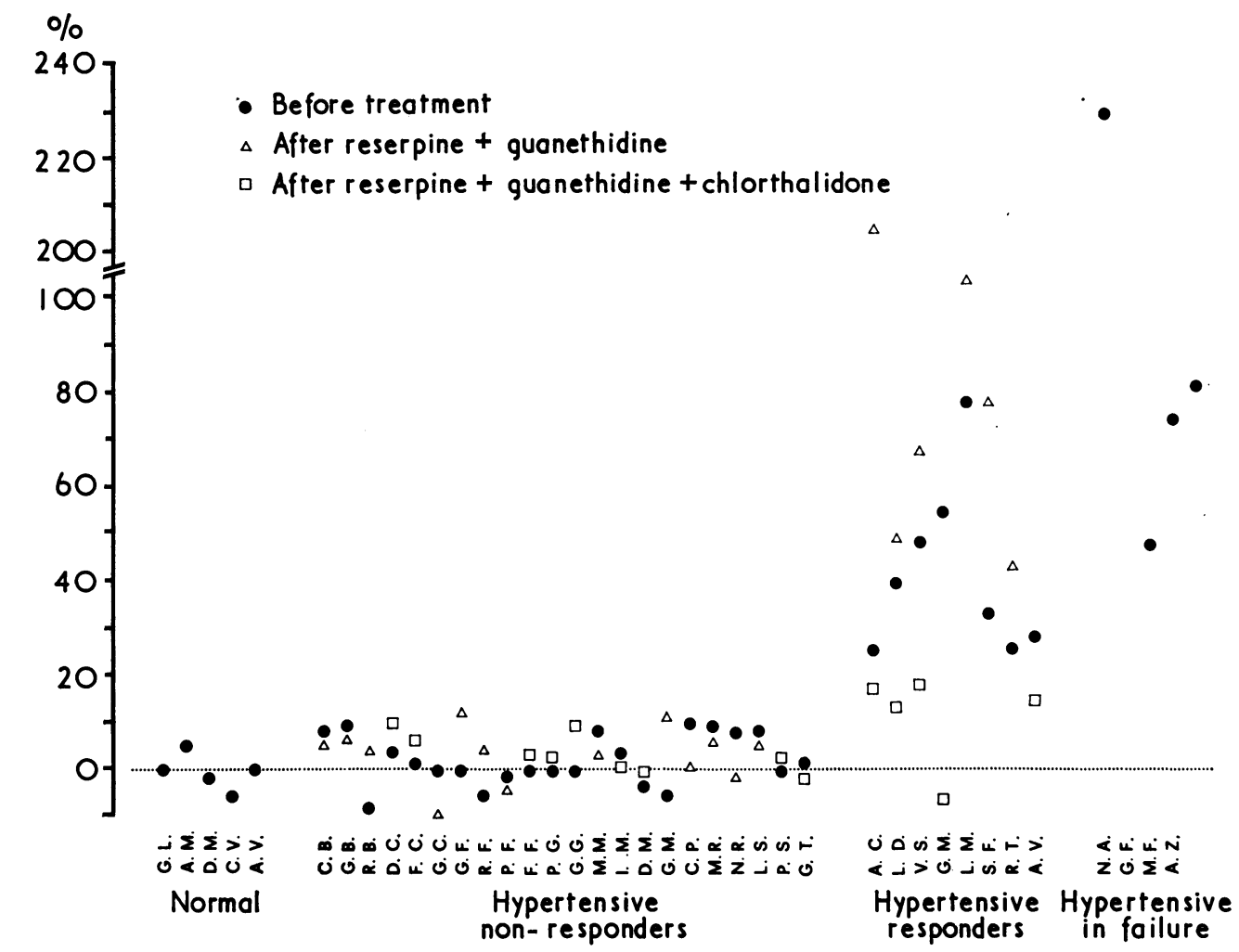

FIG. 2 Per cent changes in the mean rate of left ventricular isovolumic pressure development induced by acute digitalization.

same group who were treated with antiadrenergic agents combined with diuretic, did not develop any clinical signs of left ventricular impairment. No change in estimated myocardial performance as in the response to acute digitalis infusion was observed (patients G.M. and A.V., Fig. I and 2). The negative action of the antiadrenergic treatment and the favourable effects of the diuretic combination were even more evident in the circulatory pattern of three patients in group II, as shown in Table 4, with a repeated study before (A) and after (B) antiadrenergic therapy, and after diuretic combination (C).

Tables 5 and 6 refer to the non-responders to digitalis. Both the antiadrenergic agents alone (Table 5) and combined with diuretic (Table 6) resulted in effective lowering of the blood pressure. In none of these patients did either form of treatment induce clinical signs of cardiac decompensation. Parameters related to left ventricular function did not show significant reductions after antihypertensive therapy either with or without the diuretic combination. The response to digitalis remained in a similar range to that before treatment (see also Fig. I and 2). The patients in group I who were treated with reserpine and guanethidine had their body weight checked daily: no weight gain was detected.

A single intravenous infusion of reserpine and guanethidine in patient A.C. in group II induced a classical circulatory response (Cohn, Liptak, and Freis, 1963), i.e. a transient pressor phase, followed by a later hypotensive response (mean arterial pressure decreased from 166 to $134 \mathrm{mmHg}$ ). The hypotensive effect was associated with a reduction in mean right atrial pressure (from 3.5 to $1.5 \mathrm{mmHg}$ ), an increase in cardiac index (from 2600 to 3200 $\mathrm{ml} / \mathrm{min}$ ) as well as in the mean rates of left ventricular systolic ejection (from 80 to $93 \mathrm{ml} / \mathrm{sec} / \mathrm{m}^{2}$ ) and isovolumic pressure development (from 3.2 to 3.7 $\mathrm{mmHg} / \mathrm{msec}$ ). Previous long-term administration of the same drugs had induced left ventricular failure in this patient. 
TABLE 2 Comparison of salient clinical features in patients of Group I (non-responders) and of Group II (responders to digitalis)

\begin{tabular}{|c|c|c|c|c|c|c|c|}
\hline Patients & $\begin{array}{l}\text { Age } \\
(y r)\end{array}$ & $\begin{array}{l}\text { Duration of } \\
\text { hypertension } \\
(y r)\end{array}$ & $\begin{array}{l}\text { Brachial mean } \\
\text { arterial pressure } \\
(\mathrm{mmHg})\end{array}$ & $\begin{array}{l}\text { Fundi } \\
\text { grade }\end{array}$ & $\begin{array}{l}\text { Glomerular } \\
\text { filtration rate } \\
(\mathrm{ml} / \mathrm{min})\end{array}$ & $\begin{array}{l}\text { Electrocardio- } \\
\text { gram }\end{array}$ & $\begin{array}{l}\text { Heart } \\
\text { size }\end{array}$ \\
\hline \multicolumn{8}{|c|}{ Group I (non-responders) } \\
\hline C.B. & 66 & 5 & 123 & II & 91 & Normal & ++ \\
\hline G.B. & 44 & 2 & 147 & II & 99 & LVH and strain & +++ \\
\hline R.B. & 43 & - & 151 & II & 100 & LVH and strain & \\
\hline D.C. & 66 & II & 120 & II & 52 & LVH & Normal \\
\hline F.C. & $4 I$ & 5 & 180 & III & 50 & LVH and strain & ++++ \\
\hline G.C. & 58 & 5 & 165 & II & 89 & LVH & ++++ \\
\hline G.F. & 43 & 10 & 170 & - & 97 & LVH and strain & +++++ \\
\hline R.F. & 50 & 22 & 180 & IV & 62 & LVH and strain & ++++ \\
\hline P.F. & 55 & 2 & 122 & - & $8 \mathrm{I}$ & Normal & Normal \\
\hline F.F. & 59 & I0 & 135 & - & 83 & LVH & +++ \\
\hline P.G. & 58 & 3 & 126 & - & 83 & LVH & $+++t$ \\
\hline G.G. & 60 & 7 & $15 \mathrm{I}$ & I & 52 & LVH and strain & + \\
\hline M.M. & 50 & 20 & I 58 & III & II5 & LVH and strain & +++ \\
\hline I.M. & 23 & $\mathbf{I}$ & 140 & Normal & 92 & Normal & + \\
\hline D.M. & 48 & - & 148 & I & 55 & LVH and strain & ++ \\
\hline G.M. & 47 & 6 & 138 & I & 132 & LVH & ++ \\
\hline C.P. & 42 & 一 & 125 & Normal & 73 & LVH & +++ \\
\hline M.R. & 45 & 7 & 156 & III & 63 & LVH and strain & +++ \\
\hline N.R. & 43 & $\mathbf{I}$ & 135 & I & 98 & LVH & ++ \\
\hline L.S. & 54 & IO & 107 & - & 78 & LVH & Normal \\
\hline P.S. & 35 & $\mathbf{I}$ & 106 & - & 85 & Normal & + \\
\hline G.T. & 39 & 4 & 137 & I & 109 & Normal & Normal \\
\hline \multicolumn{8}{|c|}{ Group II (responders) } \\
\hline A.C. & 60 & 7 & I73 & IV & 55 & LVH and strain & ++ \\
\hline L.D. & 47 & 7 & 180 & II & 62 & LVH & $++t+$ \\
\hline S.F. & 32 & - & 197 & III & 63 & LVH & ++ \\
\hline G.M. & 56 & 6 & I3I & I & 88 & LVH & + \\
\hline L.M. & 67 & 3 & 116 & - & 65 & LVH & ++ \\
\hline V.S. & $4 I$ & - & 177 & III & 60 & LVH and strain & ++ \\
\hline R.T. & 43 & 13 & 160 & II & 95 & LVH & +++ \\
\hline A.V. & 38 & - & 183 & IV & 51 & LVH & +++ \\
\hline
\end{tabular}

\section{Discussion}

Seventeen patients were treated with antiadrenergic agents. Six of them developed the clinical picture of left ventricular failure during the period of treatment. The changes observed in cardiac index, mean systolic ejection rate, and mean rate of isovolumic pressure development and mean right atrial pressure were all consistent with reduced ventricular performance. The remaining II patients who had the same treatment did not develop clinical or haemodynamic signs of decompensation, and the circulatory parameters more closely related to cardiac function remained unchanged.

The 6 patients who developed failure all belonged to the group of subjects who, according to the changes induced in mean systolic ejection rate and mean rate of isovolumic pressure development, were considered responders to digitalis. On the contrary, the I I patients who did not develop cardiac decom- pensation were all non-responder to digitalis. These results support the concept that antiadrenergic drugs can induce cardiac failure in patients with a reduced margin of compensation (Gaffney and Braunwald, 1963; Dollery et al., 1960; Marley and Pare, 1956). They also suggest that, at least in hypertensive subjects, the response to digitalis, evaluated on the basis of the previously mentioned parameters, seems to be a reliable test both in estimating the degree of cardiac reserve and in predicting whether patients receiving antiadrenergic agents are liable to develop heart failure.

The almost equal quantitative changes induced by digitalis on mean systolic ejection rate and mean rate of isovolumic pressure development (Fig. I and 2) in normals and hypertensive non-responders suggest that when the function of the heart is maintained, the effects of digitalis are very small and quite similar both in the normal and in the hyper- 
TABLE 3 Average haemodynamic values before and after antiadrenergic treatment in 6 subjects in Group II

\begin{tabular}{|c|c|c|c|c|c|c|}
\hline & \multicolumn{3}{|c|}{ Before antiadrenergic treatment } & \multicolumn{3}{|c|}{ After antiadrenergic treatment } \\
\hline & $A$ & $B$ & $\%$ & $A$ & $B$ & $\%$ \\
\hline Heart rate & $\begin{array}{c}79 \\
(15)\end{array}$ & $\begin{array}{c}75 \\
(15)\end{array}$ & $(5)^{-3 \cdot 6}$ & $(6)^{56 t}$ & $\begin{array}{c}54^{\star} \\
\text { (10) }\end{array}$ & $\begin{array}{l}-4 \cdot 3 \\
(10)\end{array}$ \\
\hline Mean arterial pressure $(\mathrm{mmHg})$ & $\begin{array}{l}167 \\
(27)\end{array}$ & $\begin{array}{l}163 \\
(21)\end{array}$ & $\left(^{-I \cdot 8}\right.$ & $\begin{array}{l}18^{\star} \\
(18)\end{array}$ & $\begin{array}{l}148 * \\
(18)\end{array}$ & $\begin{array}{l}+7.5 \\
(5.5)\end{array}$ \\
\hline Mean right atrial pressure (mmHg) & (3) $3 \cdot 7$ & $\begin{array}{l}2 \cdot 7 \\
(3.5)\end{array}$ & $\begin{array}{l}-27 \\
(17)\end{array}$ & $\begin{array}{c}6 \cdot 4 \\
(3 \cdot 3)\end{array}$ & $(3 \cdot 5)^{5 \cdot 1}$ & $\begin{array}{l}-25 \\
(29)\end{array}$ \\
\hline Cardiac index $\left(\mathrm{ml} / \mathrm{min} / \mathrm{m}^{2}\right)$ & $\begin{array}{l}2300 \\
(495)\end{array}$ & $\begin{array}{l}2580 \\
(544)\end{array}$ & $\begin{array}{l}+12 \\
(9 \cdot 3)\end{array}$ & $\begin{array}{l}2060^{\star} \\
(120)\end{array}$ & $\begin{array}{l}2880 \\
(320)\end{array}$ & $\begin{array}{l}+35.5^{\star} \\
(14)\end{array}$ \\
\hline Systemic vascular resistance (dynes $\mathrm{sec} \mathrm{cm}^{-5}$ ) & $\begin{array}{l}3386 \\
(1342)\end{array}$ & $\begin{array}{l}2846 \\
(84 I)\end{array}$ & $\begin{array}{l}-12 \cdot 7 \\
\text { (II) }\end{array}$ & $\begin{array}{l}2890 \\
(834)\end{array}$ & $\begin{array}{l}2350 \\
(451)\end{array}$ & $\begin{array}{l}-17 \\
(6)\end{array}$ \\
\hline Left ventricular work ( $\mathrm{kp} \mathrm{m} / \mathrm{min}$ ) & $(\mathrm{I})^{3 \cdot 8}$ & $(I)^{4 \cdot 2}$ & $\begin{array}{l}+ \text { II } \\
\text { (I6) }\end{array}$ & $(0 \cdot 4)^{2 \cdot 9^{\star}}$ & $\begin{array}{c}4.2 \\
(0.5)^{-2}\end{array}$ & $\begin{array}{l}+34 \\
(18)\end{array}$ \\
\hline $\begin{array}{l}\text { Left ventricular isovolumic contraction time } \\
(\mathrm{msec})\end{array}$ & $\begin{array}{l}58 \\
(12)\end{array}$ & ${ }_{(12)}^{42 \cdot 5}$ & $\begin{array}{l}-27 \\
(\mathrm{II})\end{array}$ & $\begin{array}{c}63 \\
(12)\end{array}$ & $\begin{array}{c}38 \cdot 5 \\
(13 \cdot 5)\end{array}$ & $\begin{array}{l}-39 \\
(17)\end{array}$ \\
\hline Mean systolic ejection rate $\left(\mathrm{ml} / \mathrm{sec} / \mathrm{m}^{2}\right)$ & $\begin{array}{l}132 \\
(54)\end{array}$ & $\begin{array}{l}166 \\
(31)\end{array}$ & $\begin{array}{r}+25 \\
(7 \cdot 5)\end{array}$ & $\begin{array}{l}12 I^{\star} \\
(12)\end{array}$ & $\begin{array}{l}21 I^{\star} \\
(25)\end{array}$ & $\begin{array}{l}+73 t \\
(9)\end{array}$ \\
\hline $\begin{array}{l}\text { Mean isovolumic pressure development rate } \\
\text { (mmHg/msec) } \\
\text { Symptoms }\end{array}$ & $\begin{array}{l}(0 \cdot 2 \cdot 2 \\
\text { None }\end{array}$ & $(0.5)^{3.05}$ & $\begin{array}{l}+42 \\
(20)\end{array}$ & $\begin{array}{l}1 \cdot 6^{\star} \\
(0 \cdot 4) \\
\text { Nocturnal } \\
\text { dyspnoea } \\
\text { Lung rales }\end{array}$ & $(0.5)^{3 \cdot I^{\star}}$ & $\begin{array}{l}+60 t \\
(66)\end{array}$ \\
\hline
\end{tabular}

A, control; B, after digitalis; $\%$, percentage change in control values. SD in parentheses.

$\star P<0.05 ;+P<0.001$.

TABLE 4 Haemodynamic parameters in 3 patients in Group II before and after antiadrenergic treatment and after diuretic combination

\begin{tabular}{|c|c|c|c|c|c|c|c|c|c|c|c|c|c|c|c|c|c|c|c|}
\hline \multirow[t]{2}{*}{ Patient } & & \multicolumn{2}{|c|}{$\begin{array}{l}\text { Heart } \\
\text { rate }\end{array}$} & \multicolumn{2}{|c|}{$\begin{array}{l}\text { Mean } \\
\text { arterial } \\
\text { pressure } \\
(\mathrm{mmHg})\end{array}$} & \multicolumn{2}{|c|}{$\begin{array}{l}\text { Mean right } \\
\text { atrial } \\
\text { pressure } \\
(m m H g)\end{array}$} & \multicolumn{2}{|c|}{$\begin{array}{l}\text { Cardiac } \\
\text { index } \\
\left(\mathrm{ml} / \min / \mathrm{m}^{2}\right)\end{array}$} & \multicolumn{2}{|c|}{$\begin{array}{l}\text { Systemic } \\
\text { vascular } \\
\text { resistance } \\
(\text { dynes sec } \\
\left.\text { cm }^{-5}\right)\end{array}$} & \multicolumn{2}{|c|}{$\begin{array}{l}\text { Left ven- } \\
\text { tricular } \\
\text { work } \\
(\mathrm{kp} \mathrm{m} / \mathrm{min})\end{array}$} & \multicolumn{2}{|c|}{$\begin{array}{l}L V \text { iso- } \\
\text { volumic } \\
\text { contraction } \\
\text { time (msec) }\end{array}$} & \multicolumn{2}{|c|}{$\begin{array}{l}\text { Mean } \\
\text { systolic } \\
\text { ejection } \\
\text { rate } \\
\left(\mathrm{ml} / \mathrm{sec} / \mathrm{m}^{2}\right)\end{array}$} & \multirow{2}{*}{\multicolumn{2}{|c|}{$\begin{array}{l}\text { Mean iso- } \\
\text { volumic } \\
\text { pressure } \\
\text { development } \\
\text { rate (mmHgl } \\
\text { msec) } \\
\quad \%\end{array}$}} \\
\hline & & & $\%$ & & $\%$ & & $\%$ & & $\%$ & & $\%$ & & $\%$ & & $\%$ & & $\%$ & & \\
\hline V.S. & $\begin{array}{l}\text { A } \\
\text { B } \\
\text { C }\end{array}$ & $\begin{array}{l}70 \\
60 \\
57\end{array}$ & $\begin{array}{c}-\mathrm{II} \\
0 \\
0\end{array}$ & $\begin{array}{l}177 \\
160 \\
146\end{array}$ & $\begin{array}{l}+4 \\
+6 \\
+11\end{array}$ & $\begin{array}{l}3 \cdot 3 \\
3 \cdot 3 \\
3\end{array}$ & $\begin{array}{l}-15 \\
-69 \\
-16\end{array}$ & $\begin{array}{l}2900 \\
2000 \\
2780\end{array}$ & $\begin{array}{l}+11 \\
+46 \\
+10\end{array}$ & $\begin{array}{l}3196 \\
4084 \\
2700\end{array}$ & $\begin{array}{l}-4 \\
-24 \\
+2\end{array}$ & $\begin{array}{l}5 \\
3 \cdot 2 \\
4\end{array}$ & $\begin{array}{l}+17 \\
+55 \\
+24\end{array}$ & $\begin{array}{l}45 \\
50 \\
40\end{array}$ & $\begin{array}{l}-33 \\
-40 \\
-25\end{array}$ & $\begin{array}{l}138 \\
117 \\
150\end{array}$ & $\begin{array}{l}+22 \\
+41 \\
+6\end{array}$ & $\begin{array}{l}3 \\
2 \cdot 4 \\
3 \cdot 2\end{array}$ & $\begin{array}{l}+49.5 \\
+67 \\
+18.5\end{array}$ \\
\hline L.D. & $\begin{array}{l}\text { A } \\
\text { B } \\
\text { C }\end{array}$ & $\begin{array}{l}83 \\
60 \\
54\end{array}$ & $\begin{array}{l}-9 \\
-18 \\
0\end{array}$ & $\begin{array}{l}180 \\
156 \\
118\end{array}$ & $\begin{array}{l}-9 \\
+1 \\
+4\end{array}$ & $\begin{array}{c}6 \\
12 \\
5.5\end{array}$ & $\begin{array}{l}-43 \\
-20 \\
-30\end{array}$ & $\begin{array}{l}2370 \\
1850 \\
2030\end{array}$ & $\begin{array}{l}+9 \\
+23 \\
+12\end{array}$ & $\begin{array}{l}3050 \\
3280 \\
2270\end{array}$ & $\begin{array}{l}-16 \\
-19 \\
-1\end{array}$ & $\begin{array}{l}4 \cdot 3 \\
2 \cdot 9 \\
2 \cdot 4\end{array}$ & $\begin{array}{l}-1 \\
+25 \\
+16\end{array}$ & $\begin{array}{l}70 \\
60 \\
60\end{array}$ & $\begin{array}{l}-28 \\
-16 \\
-16\end{array}$ & $\begin{array}{l}229 \\
218 \\
286\end{array}$ & $\begin{array}{l}+28 \\
+53 \\
+11\end{array}$ & $\begin{array}{l}2 \\
1 \cdot 8 \\
2 \cdot 3\end{array}$ & $\begin{array}{l}+40 \\
+49 \\
+13.5\end{array}$ \\
\hline A.C. & $\begin{array}{l}\mathbf{A} \\
\mathbf{B} \\
\mathbf{C}\end{array}$ & $\begin{array}{l}81 \\
63 \\
66\end{array}$ & $\begin{array}{l}-1 \\
+10 \\
-9\end{array}$ & $\begin{array}{l}173 \\
130 \\
140\end{array}$ & $\begin{array}{l}\quad 0 \\
+15 \\
+3\end{array}$ & $\begin{array}{l}1 \\
6 \cdot 5 \\
5 \cdot 5\end{array}$ & $\begin{array}{c}0 \\
-52 \\
-27\end{array}$ & $\begin{array}{l}2140 \\
2090 \\
2370\end{array}$ & $\begin{array}{l}+11 \\
+37 \\
+0.4\end{array}$ & $\begin{array}{l}3600 \\
2860 \\
2830\end{array}$ & $\begin{array}{l}+2 \\
-19 \\
+4\end{array}$ & $\begin{array}{l}3 \cdot 7 \\
2 \cdot 7 \\
3 \cdot 3\end{array}$ & $\begin{array}{l}+12 \\
+38 \\
+4\end{array}$ & $\begin{array}{l}50 \\
50 \\
35\end{array}$ & $\begin{array}{l}-10 \\
-60 \\
-14\end{array}$ & $\begin{array}{l}106 \\
104 \\
117\end{array}$ & $\begin{array}{l}+28 \\
+38 \\
+8\end{array}$ & $\begin{array}{l}2 \cdot 2 \\
1 \cdot 6 \\
2 \cdot 8\end{array}$ & $\begin{array}{l}+24 \\
+217 \\
+17\end{array}$ \\
\hline Means & $\begin{array}{l}\text { A } \\
\text { B } \\
\text { C }\end{array}$ & $\begin{array}{l}78 \\
60 \\
59\end{array}$ & $\begin{array}{l}-7 \\
-2 \\
-3\end{array}$ & $\begin{array}{l}176 \\
148 \\
134\end{array}$ & $\begin{array}{l}-1 \\
+7 \\
+6\end{array}$ & $\begin{array}{l}3 \\
7 \\
3 \cdot 5\end{array}$ & $\begin{array}{l}-19 \\
-40 \\
-24\end{array}$ & $\begin{array}{l}2470 \\
1980 \\
2390\end{array}$ & $\begin{array}{l}+10 \\
+35 \\
+7\end{array}$ & $\begin{array}{l}3280 \\
3400 \\
2600\end{array}$ & $\begin{array}{l}-6 \\
-2 I \\
+I\end{array}$ & $\begin{array}{l}4 \cdot 3 \\
2 \cdot 9 \\
3 \cdot 3\end{array}$ & $\begin{array}{l}+9 \\
+39 \\
+15\end{array}$ & $\begin{array}{l}53 \\
54 \\
41\end{array}$ & $\begin{array}{l}-23 \\
-38 \\
-7\end{array}$ & $\begin{array}{l}157 \\
153 \\
184\end{array}$ & $\begin{array}{l}+26 \\
+44 \\
+9\end{array}$ & $\begin{array}{l}2.4 \\
1.9 \\
2.9\end{array}$ & $\begin{array}{l}+38 \\
+107 \\
+6\end{array}$ \\
\hline
\end{tabular}

A, before and B, after antiadrenergic therapy; C, after diuretic combination.

$\%$, per cent changes induced by digitalization. 
TABLE 5 Average haemodynamic values before and after antiadrenergic treatment in II subjects in Group I

\begin{tabular}{|c|c|c|c|c|c|c|}
\hline & \multicolumn{3}{|c|}{ Before antiadrenergic treatment } & \multicolumn{3}{|c|}{ After antiadrenergic treatment } \\
\hline & $A$ & $B$ & $\%$ & $A$ & $B$ & $\%$ \\
\hline Heart rate & $(8)^{74}$ & $(9)^{70}$ & $(3)^{-4 \cdot 4}$ & $(6)^{60 \dagger}$ & $(7)^{59 \dagger}$ & $\begin{array}{l}-1 \cdot 9 \\
(7)\end{array}$ \\
\hline Mean arterial pressure $(\mathrm{mmHg})$ & $\begin{array}{l}140 \\
(20)\end{array}$ & $\begin{array}{l}137 \\
\text { (I6) }\end{array}$ & $\left(^{-I \cdot 3}\right.$ & $\begin{array}{l}\text { 126t } \\
\text { (19) }\end{array}$ & $\begin{array}{l}\text { I31 } \\
(20)\end{array}$ & $\begin{array}{l}+4^{*} \\
(5)\end{array}$ \\
\hline Mean right atrial pressure (mmHg) & $(I)^{3 \cdot 7}$ & (I) $3 \cdot 2$ & $\begin{array}{l}-11 \\
(24)\end{array}$ & (2) ${ }^{4 \cdot 8}$ & (2) 4.5 & $\begin{array}{l}-4 \\
(16)\end{array}$ \\
\hline Cardiac index $\left(\mathrm{ml} / \mathrm{min} / \mathrm{m}^{2}\right)$ & $\begin{array}{l}2780 \\
(600)\end{array}$ & $\begin{array}{l}2725 \\
(620)\end{array}$ & $\left(^{-2}\right.$ & $\begin{array}{l}2650 \\
(420)\end{array}$ & $\begin{array}{l}2640 \\
(470)\end{array}$ & $\begin{array}{l}-0.4 \\
(4.5)\end{array}$ \\
\hline Systemic vascular resistance (dynes $\mathrm{sec} \mathrm{cm}^{-5}$ ) & $\begin{array}{l}2254 \\
(600)\end{array}$ & $\begin{array}{l}2252 \\
(570)\end{array}$ & ${ }^{+3}+0.3$ & $\begin{array}{l}2054 \\
(490)\end{array}$ & $\begin{array}{l}2160 \\
(550)\end{array}$ & $\begin{array}{c}+4.9 \\
(6.5)\end{array}$ \\
\hline Left ventricular work ( $\mathrm{kp} \mathrm{m} / \mathrm{min}$ ) & $(I)^{4}$ & (I) 3.7 & $\begin{array}{l}-4 \cdot 2 \\
(6 \cdot 3)\end{array}$ & $(0.5)^{3 \cdot 3^{\star}}$ & $(0.5)^{3.4}$ & $\begin{array}{l}+3 \cdot 6 \\
(8)\end{array}$ \\
\hline Left ventricular isovolumic contraction time (msec) & $\begin{array}{r}53 \\
(7 \cdot 5)\end{array}$ & $\begin{array}{l}47 \\
\text { (I0) }\end{array}$ & $\begin{array}{l}-10 \\
\text { (10) }\end{array}$ & $(\mathrm{II})$ & $\begin{array}{c}44 \\
\text { (10) }\end{array}$ & $\begin{array}{c}0 \\
\text { (II) }\end{array}$ \\
\hline Mean systolic ejection rate $\left(\mathrm{ml} / \mathrm{sec} / \mathrm{m}^{2}\right)$ & $\begin{array}{l}135 \\
\text { (30) }\end{array}$ & $\begin{array}{l}129 \\
(31)\end{array}$ & $\begin{array}{c}+2 \cdot 7 \\
(3.5)\end{array}$ & $\begin{array}{l}140 \\
(23)\end{array}$ & $\begin{array}{l}\text { I44 } \\
\text { (25) }\end{array}$ & $\begin{array}{l}+2 \cdot 7 \\
(4)\end{array}$ \\
\hline $\begin{array}{l}\text { Mean isovolumic pressure development rate } \\
\text { (mmHg/msec) } \\
\text { Symptoms }\end{array}$ & $\begin{array}{l}2.05 \\
(0.36) \\
\text { None }\end{array}$ & $\begin{array}{c}2 \cdot 1 \\
(0.43)\end{array}$ & $(8)^{+5}$ & $\begin{array}{l}2 \cdot 13 \dagger \\
(0.46) \\
\text { None }\end{array}$ & $\begin{array}{c}2 \cdot 2 \\
(0.48)\end{array}$ & $\begin{array}{l}+5.5 \\
(4.4)\end{array}$ \\
\hline
\end{tabular}

A, control; B, after digitalis; \%, per cent changes in control values after digitalis; SD in parentheses.

$\star \mathrm{P}<0.05 ;+\mathrm{P}<0.001$.

TABLE 6 Average haemodynamic values before and after antiadrenergic and diuretic treatment in II subjects in Group I

\begin{tabular}{|c|c|c|c|c|c|c|}
\hline & \multicolumn{3}{|c|}{$\begin{array}{l}\text { Before antiadrenergic and diuretic } \\
\text { treatment }\end{array}$} & \multicolumn{3}{|c|}{$\begin{array}{l}\text { After antiadrenergic and diuretic } \\
\text { treatment }\end{array}$} \\
\hline & $A$ & $B$ & $\%$ & $A$ & $B$ & $\%$ \\
\hline Heart rate & $(9)^{69}$ & $(9)^{66}$ & $\begin{array}{c}-3 \cdot 3 \\
(2 \cdot 5)\end{array}$ & $(9)^{60}$ & $(8)^{58}$ & $\begin{array}{l}-1 \cdot 8 \\
(3)\end{array}$ \\
\hline Mean arterial pressure (mmHg) & $\begin{array}{l}144 \\
(22)\end{array}$ & $\begin{array}{l}143 \\
(20)\end{array}$ & $\left(^{-0.7}\right.$ & $\begin{array}{l}\text { II } 4 \dagger \\
\text { (I8) }\end{array}$ & $\begin{array}{l}\text { IIst } \\
(2 I)\end{array}$ & $\begin{array}{l}+0.9 \\
(3)\end{array}$ \\
\hline Mean right atrial pressure $(\mathrm{mmHg})$ & $\begin{array}{l}2 \cdot 7 \\
(1 \cdot 5)\end{array}$ & $(I \cdot 5)^{2 \cdot 4}$ & $\begin{array}{l}-10.5 \\
(22)\end{array}$ & $(1 \cdot 5)$ & $\left(\begin{array}{ll}2 \cdot 5 \\
(1 \cdot 5)\end{array}\right.$ & $\frac{-8 \cdot 3}{(16)}$ \\
\hline Cardiac index $\left(\mathrm{ml} / \mathrm{min} / \mathrm{m}^{2}\right)$ & $\begin{array}{l}2690 \\
(630)\end{array}$ & $\begin{array}{l}2620 \\
(550)\end{array}$ & $\begin{array}{l}-2 \\
(4 \cdot 9)\end{array}$ & $\begin{array}{l}2450 \\
(420)\end{array}$ & $\begin{array}{l}2400 \\
(380)\end{array}$ & $\begin{array}{l}-2 \\
(4 \cdot 3)\end{array}$ \\
\hline Systemic vascular resistance (dynes $\mathrm{sec} \mathrm{cm}^{-5}$ ) & $\begin{array}{l}2400 \\
(840)\end{array}$ & $\begin{array}{l}2450 \\
(850)\end{array}$ & $\begin{array}{l}+2 \cdot 5 \\
(5 \cdot 5)\end{array}$ & $\begin{array}{l}2115^{\star} \\
(710)\end{array}$ & $\begin{array}{l}2120^{\star} \\
(690)\end{array}$ & $\begin{array}{l}+0.4 \\
(9)\end{array}$ \\
\hline Left ventricular work ( $\mathrm{kp} \mathrm{m} / \mathrm{min}$ ) & $(\mathrm{I})^{3 \cdot 9}$ & $(\mathrm{I})^{3.8}$ & ${ }_{(9)}^{+I \cdot I}$ & $(0.5)$ & $(0 \cdot 7)^{2 \cdot 7 \dagger}$ & $\begin{array}{l}-0 \cdot 1 \\
(6 \cdot 4)\end{array}$ \\
\hline Left ventricular isovolumic contraction time (msec) & $\begin{array}{c}52 \\
(10)\end{array}$ & $\begin{array}{r}50 \\
(8 \cdot 5)\end{array}$ & $(5)^{-2 \cdot 8}$ & ${ }_{(12)}^{43 t}$ & $\begin{array}{l}43^{\star} \\
(\mathrm{II})\end{array}$ & $\begin{array}{c}0 \\
\text { (10) }\end{array}$ \\
\hline Mean systolic ejection rate $\left(\mathrm{ml} / \mathrm{sec} / \mathrm{m}^{2}\right)$ & $\begin{array}{l}148 \\
(34)\end{array}$ & $\begin{array}{l}141 \\
(29)\end{array}$ & $\left(^{-4}\right.$ & $(27)^{145}$ & $\begin{array}{l}145 \\
(40)\end{array}$ & $\begin{array}{c}0 \\
(4 \cdot 5)\end{array}$ \\
\hline $\begin{array}{l}\text { Mean isovolumic pressure development rate } \\
\text { (mmHg/msec) } \\
\text { Symptoms }\end{array}$ & $\begin{array}{l}2.05 \\
(0.24) \\
\text { None }\end{array}$ & $\begin{array}{c}2 \cdot 08 \\
(0.27)\end{array}$ & $\begin{array}{l}+0.8 \\
(1 \cdot 7)\end{array}$ & $\begin{array}{l}2 \cdot 03 \\
(0.45) \\
\text { None }\end{array}$ & $(0.35)$ & $\begin{array}{l}(7)^{\circ} \\
0\end{array}$ \\
\hline
\end{tabular}

A, control; $B$, after digitalis; $\%$, per cent changes in control values after digitalis. $S D$ in parentheses. $\star \mathrm{P}<0.05 ;+\mathrm{P}<0.001$. 
tensive patients. The overlap in magnitude of response to digitalis between hypertensive responders and hypertensives in failure indicates that the hearts in incipient insufficiency behave, when digitalis is administered, in a way qualitatively and quantitatively similar to that of those in overt decompensation. But the clear distinction in the degree of response between group I and group II hypertensive patients suggests a different pattern, after digitalis, between cardiac compensation and cardiac decompensation, both latent or overt.

The clear-cut difference between subjects in our series who responded to digitalis and those who did not raised the question that group I and group II may have varied in other respects as well. The two groups were compared with respect to haemodynamic patterns and clinical features. Though patients in group I more often showed haemodynamic levels closer to normal than those in group II, the overlap between the two groups was so great that no significant haemodynamic difference between them could be established. The degree of hypertension was almost constantly greater in the patients in group II than in those in group I. Data concerning the clinical features indicate that all of the responders to digitalis had electrocardiographic signs of left ventricular hypertrophy, or left ventricular hypertrophy and strain; in this group also grade 3 and 4 retinopathy was more frequent. Though no conclusion can be drawn, it appears that some interrelation exists between severity of hypertension and cardiac reserve.

As regards the mechanism by which failure is induced, reserpine and guanethidine could depress cardiac performance either by interrupting the sympathetic drive to the heart, or by promoting fluid retention, or both. However, a dramatic improvement of dyspnoea was observed by Dollery et al. (1960) in a patient with acute pulmonary oedema who was given guanethidine. Cohn et al. (1963) found that intravenous infusion of guanethidine in hypertensive subjects with congestive heart failure improved cardiac function. The beneficial effect was thought to be the result of both a decrease in right atrial filling pressure due to increased capacity of the peripheral venous system and a reduction in systemic vascular resistance. These observations appear in contrast with the negative influence of guanethidine on cardiac function in our patients with a reduced margin of cardiac reserve. Cardiac failure occurred despite a considerable reduction in systemic vascular resistance. Patient A.C. may be of some interest here, because chronic administration of guanethidine and reserpine induced left ventricular failure, while his cardiac performance obviously improved after acute intravenous infusion of the same drugs. A reasonable explanation might be that the negative influence of fluid retention induced by chronic antiadrenergic treatment plus sympathetic blockade overwhelms the favourable effect of the reduced left ventricular afterload.

It is difficult to say whether fluid retention is a cause or a consequence of cardiac failure. On the basis of changes in body weight, the present observations suggest that fluid retention is more likely to occur in those patients who develop heart failure; however, the data are insufficient for any definite conclusion. It has been suggested that the fall in blood pressure, with its consequent effects on the renal circulation, is the cause of fluid retention produced by hypotensive drugs (Rønnov-Jessen, I955). In Smith's (1965b) series, the creatinine clearance values fell significantly in most of the patients treated with guanethidine. The author, however, considered it unwarranted to ascribe to this association a cause-and-effect relation. From our observations, the explanation of fluid retention occurring as a result of a fall in glomerular filtration rate consequent to fall in blood pressure seems unsatisfactory; in fact changes in glomerular filtration rate were insignificant, and in addition the hypotensive responses were approximately the same in group I and II patients.

No clinical or haemodynamic signs of cardiac failure were detected in patients who had the diuretic added to their regimen. Diuretics obviously were effective in preventing heart failure in 2 subjects in group II and in returning to the pretreatment levels the circulatory parameters of those subjects who developed cardiac decompensation after antiadrenergic therapy used alone. The reduction of volume load and of pressure load (potentiation of the hypotensive effect) on the heart may provide possible explanation of the improved cardiac performance observed after the diuretic.

\section{References}

Cohn, J. N., Liptak, T. E., and Freis, E. D. (I963). Haemodynamic effects of guanethidine in man. Circulation Research, 12, 298.

Dollery, C. T., Emslie-Smith, D., and Milne, M. D. (1960). Clinical and pharmacological studies with guanethidine in the treatment of hypertension. Lancet, 2, 381.

Gaffney, T. E., and Braunwald, E. (1963). Importance of the adrenergic nervous system in the support of circulatory function in patients with congestive heart failure. American fournal of Medicine, 34, 320.

Kassebaum, D. G., and Griswold, H. E. (1970). Digitalis in non-failing cardiac diseases. Progress in Cardiovascular Diseases, 12, 484.

Leishman, A. W. D., Matthews, H. L., and Smith, A. J. (1959). Guanethidine. Hypotensive drug with prolonged action. Lancet, 2, 1044.

Marley, E., and Pare, C. M. B. (1956). Cardiac failure with reserpine. British Medical fournal, I, 267. 
Murphy, G. W., Schreiner, B. F., Bleakley, P. L., and Yu, P. N. (1964). Left ventricular performance following digitalization in patients with and without heart failure. Circulation, 30, 358.

New York Heart Association, Criteria Committee (1964). Disease of the Heart and Blood Vessels. Nomenclature and Criteria for Diagnosis, 6th ed. Little, Brown, Boston; Churchill, London.

Perera, G. A. (1955). Edema and congestive failure related to administration of rauwolfia serpentina. Fournal of the American Medical Association, 159, 439.

Rønnov-Jessen, V. (1955). Heart failure from retention of salt and water caused by treatment with pentapyrrolidinium bitartrate. Lancet, $1,122$.

Smirk, F. H., and McQueen, E. G. (1955). Comparison of rescinnamine and reserpine as hypotensive agents. Lancet, 2, 115 .

Smith, A. J. (1965a). Clinical features of fluid retention complicating treatment with guanethidine. Circulation, 3I, 485 .

Smith, A. J. (1965b). Fluid retention produced by guanethidine. Changes in body exchangeable sodium, blood volume, and creatinine clearance. Circulation, 31, 490.

Weissler, A. M., Harris, W. S., and Schoenfeld, C. D. (1968). Systolic time intervals in heart failure in man. Circulation, 37, 149.

Requests for reprints to Dr. Maurizio Guazzi, Istituto di Clinica Medica II, Padiglione SACCO, Via F. Sforza, 35, 20122 Milano, Italy. 